\title{
Variability of high rainfalls and related synoptic situations causing heavy floods at the northern foothills of the Tatra Mountains
}

\author{
Tadeusz Niedźwiedź • Ewa Lupikasza • Iwona Pińskwar • \\ Zbigniew W. Kundzewicz • Markus Stoffel • \\ Lukasz Małarzewski
}

Received: 28 June 2013 / Accepted: 26 January 2014 / Published online: 20 February 2014

(C) The Author(s) 2014. This article is published with open access at Springerlink.com

\begin{abstract}
This contribution provides the basics of the climatology of the Polish Tatra Mountains in a nutshell, with particular reference to intense precipitation and its relation to atmospheric circulation. Variability of various precipitation characteristics, including selected indices of intense precipitation in Zakopane and at Kasprowy Wierch, is illustrated in this paper. None of the trends in these characteristics and indices calculated for the entire time interval exhibit a statistical significance, but short-time fluctuations are evident. The occurrence of intense precipitation in the Tatra Mountains is strongly related to three circulation types. These situations $(\mathrm{Nc}, \mathrm{NEc}, \mathrm{Bc})$ are associated with cyclones following track $\mathrm{Vb}$ after van Bebber. In addition to changing frequencies of circulation, this study also reveals an increase in the frequency of the circulation types associated with extreme precipitation.
\end{abstract}

\section{Introduction}

The Polish-Swiss research project FLORIST (Flood risk on the northern foothills of the Tatra Mountains; Kundzewicz

T. Niedźwiedź $(\bowtie) \cdot$ E. Łupikasza $・$ Ł. Małarzewski

Faculty of Earth Sciences, University of Silesia, Sosnowiec, Poland

e-mail: tadeusz.niedzwiedz@us.edu.pl

I. Pińskwar · Z. W. Kundzewicz

Institute for Agricultural and Forest Environment, Polish Academy of Sciences, Poznań, Poland

\section{Stoffel}

Dendrolab.ch, Institute of Geological Sciences, University of Bern, Bern, Switzerland

M. Stoffel

Institute for Environmental Sciences, University of Geneva, Geneva, Switzerland et al. 2013) deals with the evaluation of flood hazard and risk on the northern foothills of the Tatra Mountains, where considerable potential exists for flood generation. One of the competence clusters on which the project is focused is observation-based climatology of climatic extremes (Heino et al. 1999). One of the topical areas of the FLORIST project is the analysis of change in intense precipitation and "wet" weather circulation patterns occurring in the study area. The project aims at creating a comprehensive information database on past torrential disasters and floods in the northern foothills of the Tatra Mountains and their triggers as well as on change detection in intense precipitation and in circulation patterns. The aim of this paper is to recognize long-term changes in flood precipitation and its linkage to atmospheric circulation at the stations located in the Polish Tatra Mountains.

This contribution discusses the long-term changes in the warm half-year (May-October) and summer season precipitation as causing flood events and in selected high precipitation indices (maximum daily precipitation, maximum 3- and 5-day precipitation totals, number of days with precipitation $\geq 30$ and $\geq 50 \mathrm{~mm}$ ). The relations between the occurrence of high daily precipitation totals ( $\geq 30$ and $\geq 50 \mathrm{~mm}$ ) and atmospheric circulation are documented, and the weather patterns favouring the occurrence of the very highest precipitation $\left(\geq 100 \mathrm{~mm} 24 \mathrm{~h}^{-1}\right.$ ) are analysed. The climate conditions of the Tatra Mountains undergo rapid changes with altitude. Interconnection between this specific climate and orography is conductive to generate floods which affect wide areas of Poland. The basics of Tatra Mountains climate and the statistics of high precipitation, presented in the following as a background for further investigations, were drawn from material published in the past (e.g. Hess 1965; Konček 1974; Niedźwiedź 1992; Cebulak and Niedźwiedź 1998; Niedźwiedź 2003a; Ustrnul and Czekierda 2009). In addition, 
we analyse meteorological data from two synoptic stations of the Institute of Meteorology and Water Management-State Research Institute (IMGW-PIB) with the longest series of daily precipitation totals. Part of data for the period 2000 2012 has been obtained from the SYNOP messages database OGIMET (Valor 2013).

\section{The basics of the Tatra Mountains climate}

The topography and climate of Poland play an important role in the spatial and temporal distribution of flood hazards. The Tatra Mountains (Tatry in Polish and Slovak) are the highest range of the massive arc of the Carpathian Mountains, spreading over a distance of about $1,300 \mathrm{~km}$ and passing through several Central and Eastern European countries. The Polish Tatra Mountains, located in the southernmost part of the country (Fig. 1), record the highest precipitation totals in Poland, due to orographic effects, and largely contribute to flood generation, thereby affecting large areas of the Polish foothills and lowlands to the north.

The Tatra Mountains are an important barrier to the movement of air masses. Air temperature is the most important climatic element, which strongly depends on elevation and exerts a considerable influence upon the vegetation and landscape (Hess 1965; Niedźwiedź 1992). For example, on the northern slopes of the Tatra Mountains, mean annual temperature ranges from about $6{ }^{\circ} \mathrm{C}$ at elevations of $600-650 \mathrm{~m}$ at the bottom of the Nowy Targ Basin to $-4{ }^{\circ} \mathrm{C}$ on the highest peaks of the Tatra ridge (Tables 1 and 2). Hess (1965) proposed to divide the region in six distinct vertical climatic belts of $2 \mathrm{~K}$ width, based on mean annual temperature. The upper treeline $(1,550 \mathrm{~m}$ above sea level (a.s.l.)) is consistent with the annual isotherm of $2{ }^{\circ} \mathrm{C}$. The subalpine belt with Pinus mugo covers elevations from 1,550 to $1,850 \mathrm{~m}$, where the mean annual temperature drops to $0{ }^{\circ} \mathrm{C}$. A belt of alpine meadows extends from 1,850 to $2,200 \mathrm{~m}$ a.s.l. Above 2,200 $\mathrm{m}$ (semi-nival belt), bare rock and lichens predominate, and snow precipitation is more frequent than rainfall. Here, the duration of snow cover extends 230 days per year. The altitudinal range determining the vertical climate and vegetation zones is distinctly different between the northern and southern sides of the Tatra Mountains. Borders of particular vertical climatic zones are consistently higher, by 50-200 m, on the southern side of Tatra Mountains.

The greatest annual temperature range (ATR), defined as the difference between the mean temperatures of the warmest and coolest months, is $21.5 \mathrm{~K}$ in Nowy Targ Basin and decreases to $<16 \mathrm{~K}$ on the mountain peaks above $2,000 \mathrm{~m}$ (Table 2). Absolute temperatures on the northern foothills of the Tatra Mountains range from less than $-40{ }^{\circ} \mathrm{C}$ in $1928 / 1929$, the coldest winter of the twentieth century (Poronin $-40.4{ }^{\circ} \mathrm{C}$ on 10 February 1929 ), to $35^{\circ} \mathrm{C}$ in Nowy Targ in summer (Table 2). In Nowy Targ, the largest difference between absolute minimum $\left(-36{ }^{\circ} \mathrm{C}\right)$ and maximum $\left(35^{\circ} \mathrm{C}\right)$ temperatures ever recorded is $71 \mathrm{~K}$. On the summit of Lomnicky štít $(2,635 \mathrm{~m})$, the difference between absolute minimum $\left(-30.5^{\circ} \mathrm{C}\right)$ and maximum $\left(+17.8^{\circ} \mathrm{C}\right)$ temperatures is $48.3 \mathrm{~K}$, and temperatures may fall below $0{ }^{\circ} \mathrm{C}$ during 286 days per year. The longest period with uninterrupted negative temperatures was 198 days (i.e. ice days with $T_{\max }$ $<0{ }^{\circ} \mathrm{C}$ ), and freeze-thaw conditions (with $T_{\max }>0{ }^{\circ} \mathrm{C}$ and $T_{\min } \leq 0{ }^{\circ} \mathrm{C}$ ) have been recorded on 88 days (Niedźwiedź 1992). At altitudes close to $2,000 \mathrm{~m}$, the average number of ice days has decreased from 151 for the period 1951-1980 to 141 days for the period 1981-2012. During the last 62 years, it varied from 107 days in 1989 to 177 days in 1952.

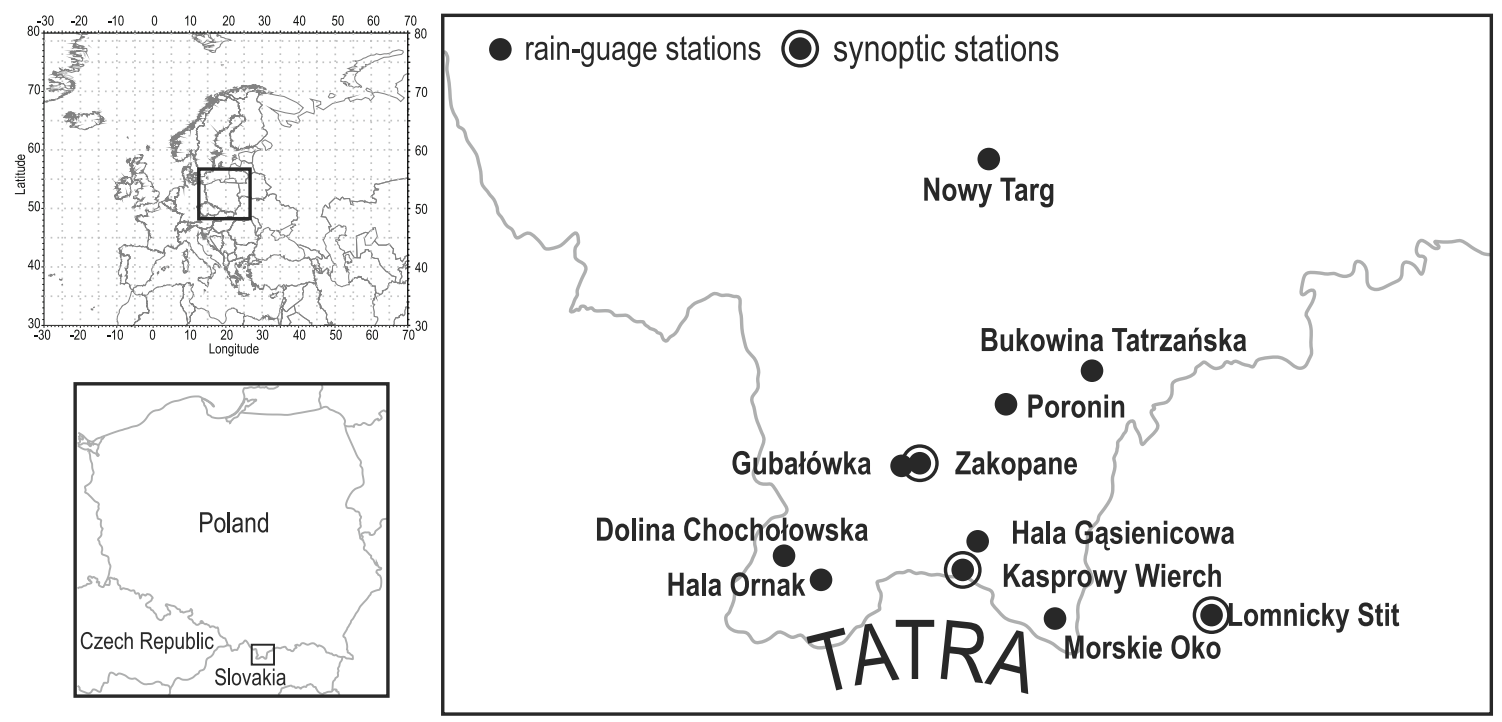

Fig. 1 Location of the study area 
Table 1 Vertical climatic zones in the Tatra Mountains and their northern foothills (after Hess 1965, 1974)

\begin{tabular}{|c|c|c|c|c|}
\hline \multirow[t]{2}{*}{ Vertical climatic zones } & \multirow[t]{2}{*}{ Vertical vegetation zones } & \multirow[t]{2}{*}{ Mean annual temperature $\left({ }^{\circ} \mathrm{C}\right)$} & \multicolumn{2}{|l|}{ Altitude in $\mathrm{m}$} \\
\hline & & & $\begin{array}{l}\text { Northern side of Tatra } \\
\text { Mountains }\end{array}$ & $\begin{array}{l}\text { Southern side of Tatra } \\
\text { Mountains }\end{array}$ \\
\hline Cold & Rocks and semi-nival belt & $<-2$ & $>2,200$ & $>2,350$ \\
\hline Moderately cold & Alpine meadows & -2 (climatic snow line $)-0$ & $2,200-1,850$ & $2,350-2,050$ \\
\hline Very cool & Subalpine belt with Pinus Mughus & $0-2$ & $1,850-1,550$ & $2,050-1,650$ \\
\hline Cool & Coniferous spruce forests with Picea & 2 (upper tree line) 4 & $1,550-1,150$ & $1,650-1,200$ \\
\hline Moderately cool & Agriculture and mixed forests & $4-6$ & $1,150-650$ & $1,200-700$ \\
\hline
\end{tabular}

The number of days with snow cover in the Tatra Mountains increases with altitude at a rate of 9 days $100 \mathrm{~m}^{-1}$ and varies from less than 120 days at the mountain base to about 220-290 days on the highest peaks (Hess 1965). On the Kasprowy Wierch summit, snow cover lasts 221 days on average (1951-2012) and varied from 184 days in 1984 to 254 days in 1974. Between 2001 and 2012 , the average duration of snow cover was 7 days shorter as compared to the entire period. In Zakopane, the average duration of snow cover was 126 days between 1914/1915 and $1998 / 1999$. The range of number of days with snow cover extended from 84 days in winter $1924 / 1925$ to 170 days in winter 1931/1932. Average maximum snow depths amount to $63 \mathrm{~cm}$. During two winters, 1924/1925 and 1960/1961, the maximum snow cover thickness did not exceed $25 \mathrm{~cm}$, and during the snowiest season (1944/1945), it reached $123 \mathrm{~cm}$ (Falarz 2002). Near the upper timberline at Hala Gasienicowa $(1,520 \mathrm{~m})$, snowpack had a thickness of $237 \mathrm{~cm}$ during that extreme winter. Snow depth on the summit of Kasprowy Wierch has been reported to amount to $355 \mathrm{~cm}$ (15 April 1995). Recently, such a deep snow cover $(335 \mathrm{~cm})$ was measured there on 21 March 2009, whereas the maximum depth did not exceed $92 \mathrm{~cm}$ in 1984 and $93 \mathrm{~cm}$ in 2011. The snow water equivalent may reach up to $581 \mathrm{~mm}$ at Kasprowy Wierch and $456 \mathrm{~mm}$ at Hala Gąsienicowa.

A statistically significant decreasing trend of snow cover duration ( -8 days 10 years $^{-1}$ ) and maximum snow cover depth $\left(-9 \mathrm{~cm} 10\right.$ years $\left.^{-1}\right)$ has been detected in Zakopane for the period 1961-1990 (Falarz 2002). No such trend can, however, be found at the scale of the twentieth century (period 1915-1999). At Kasprowy Wierch, where available records span the period 1954-1998, the highest stable condition of winter snow cover occurred in 1954-1960, 1970-1980 and 1990-1998 (Falarz 2013).

Winds are often strong in the Tatra Mountains. Mean annual wind speed at Kasprowy Wierch is about 6-7 $\mathrm{m} \mathrm{s}^{-1}$,

Table 2 Values of selected climatic variables in the Western Tatra Mountains and their northern foothills (location of stations, see Fig. 1)

\begin{tabular}{|c|c|c|c|c|c|c|c|c|c|c|}
\hline Station & $\begin{array}{l}H \\
\mathrm{~m}\end{array}$ & $\begin{array}{l}T_{\mathrm{a}} \\
{ }^{\circ} \mathrm{C}\end{array}$ & $\begin{array}{l}T_{\mathrm{c}} \\
{ }^{\circ} \mathrm{C}\end{array}$ & $\begin{array}{l}T_{\mathrm{w}} \\
{ }^{\circ} \mathrm{C}\end{array}$ & $\begin{array}{l}\text { ATR } \\
\mathrm{K}\end{array}$ & $\begin{array}{l}T_{\max } \\
{ }^{\circ} \mathrm{C}\end{array}$ & $\begin{array}{l}T_{\min } \\
{ }^{\circ} \mathrm{C}\end{array}$ & $\begin{array}{l}\text { PRA } \\
\mathrm{mm}\end{array}$ & $\begin{array}{l}d_{1.0} \\
\text { Days }\end{array}$ & $\begin{array}{l}\text { SCD } \\
\text { Days }\end{array}$ \\
\hline Lomnicky štít (Slovakia) & 2,633 & -3.7 & -11.6 & 4.2 & 15.8 & 17.8 & -30.5 & 1,645 & 174 & 236 \\
\hline Kasprowy Wierch & 1,991 & -0.8 & -8.9 & 7.3 & 16.2 & 23.0 & -30.2 & 1,721 & 188 & 223 \\
\hline Hala Gąsienicowa & 1,520 & 2.3 & -6.3 & 10.7 & 17.0 & 25.6 & -30.8 & 1,664 & 167 & 192 \\
\hline Morskie Oko & 1,408 & 2.5 & -6.7 & 11.0 & 17.7 & 27.5 & -30.4 & 1,614 & 168 & 188 \\
\hline Hala Ornak & 1,109 & 3.2 & -6.0 & 12.1 & 18.1 & 29.6 & -34.0 & 1,490 & 165 & 145 \\
\hline Dolina Chochołowska & 1,028 & 3.6 & -5.7 & 12.3 & 18.0 & 30.0 & -32.1 & 1,291 & 146 & 136 \\
\hline Gubałówka & 1,007 & 5.2 & -4.5 & 14.3 & 18.8 & 30.7 & -28.0 & 1,176 & n.a. & n.a. \\
\hline Bukowina & 868 & 5.3 & -5.2 & 15.0 & 20.2 & 30.5 & -29.3 & 854 & 114 & 119 \\
\hline Zakopane & 844 & 4.9 & -5.8 & 14.9 & 20.7 & 32.3 & -34.1 & 1,124 & 140 & 117 \\
\hline Poronin & 773 & 4.2 & -6.8 & 14.0 & 20.8 & 32.1 & -40.4 & 1,000 & 124 & 118 \\
\hline Nowy Targ & 600 & 5.4 & -5.7 & 15.8 & 21.5 & 35.0 & -36.0 & 816 & 120 & 107 \\
\hline
\end{tabular}

Sources of data: Konček (1974) and Niedźwiedź (1992); data archives of IMGW-PIB. Most of data are from the period 1931-1960 (Konček (1974)). Only $T_{\max }$ and $T_{\min }$ were taken from all available sources for the whole twentieth century

$H$ altitude, in meters; $T_{a}$ mean annual temperature, in degrees Celsius; $T_{\mathrm{c}}$ mean temperature of the coolest month, in degrees Celsius; $T_{w}$ mean temperature of the warmest month, in degrees Celsius; ATR annual temperature range $\left(T_{w}-T_{c}\right)$, in Kelvin; $T_{\max }$ absolute maximum of temperature, in degrees Celsius; $T_{\text {min }}$ absolute minimum temperature, in degrees C; $P R A$ annual precipitation, in millimeters; $d_{1.0}$ annual number of days with precipitation $\geq 1.0$ mm; $S C D$ snow cover duration, in days; n.a., not available 
and the number of days with strong wind $\left(\geq 10 \mathrm{~m} \mathrm{~s}^{-1}\right)$ exceeds 190 (Niedźwiedź 1992). Winds are predominantly southerly on the northern side and westerly at the base of the Tatra Mountains (Orawa-Nowy Targ Basin). Strong, warm and dry Foehn-type winds (Polish term: halny), occurring typically between October and May, can cause extensive damage and may considerably accelerate snow pack melting. Foehn winds may reach speeds of $>60 \mathrm{~m} \mathrm{~s}^{-1}$ on the mountain slopes and $25-30 \mathrm{~m} \mathrm{~s}^{-1}$ in the valleys. The largest damage on the northern side of the Tatra Mountains was caused by foehn wind on 6 May 1968 with maximum gusts estimated to about $80 \mathrm{~m} \mathrm{~s}^{-1}$ in Kasprowy Wierch and $40 \mathrm{~m} \mathrm{~s}^{-1}$ in Zakopane (Niedźwiedź 1992). On 19 November 2004, extremely strong westerly winds occurred between the Low and High Tatras in Slovakia with gusts exceeding $45 \mathrm{~m} \mathrm{~s}^{-1}$ (tunnel effect), causing severe wind throw of trees. The damaged forest area was in the order of 14,000 ha.

\section{Statistics of high precipitation}

The precipitation totals recorded on the northern slopes of the Tatra Mountains are the highest in Poland. Mean annual precipitation at Kasprowy Wierch (1,991 m a.s.l.) amounted to $1,765 \mathrm{~mm}$ over the interval 1951-2012, but the recorded high annual maximum precipitation of the station was $2,599 \mathrm{~mm}$ in 2001 [with $1,254 \mathrm{~mm}$ in summer (June to August) 2001, of which $651 \mathrm{~mm}$ in July 2001 alone]. Even higher annual precipitation values were recorded in 2001 at other locations, e.g. 2,628 $\mathrm{mm}$ at Hala Gąsienicowa and 2,770 $\mathrm{mm}$ at Dolina Pięciu Stawów (Lorenc 2005).

The Polish (as well as Western Carpathians) record of a single 24-h precipitation event is $300 \mathrm{~mm}$ and was observed at Hala Gasienicowa (northern side of the Tatra Mountains near the upper tree-line) on 30 June 1973. The downpour, which was above the 100-year return period 24-h value of $242 \mathrm{~mm}$,
Table 3 Comprehensive characterization of precipitation at Kasprowy Wierch (1,991 m a.s.l.) and Zakopane (844 $\mathrm{m}$ a.s.1.) for 1951-2006, based on Pińskwar (2009, 2010). Data were provided by IMGW-PIB. Updates, spanning the period 1951-2010 and including the events of 2010, are given as a footnote

\footnotetext{
${ }^{\text {a }}$ Precipitation characteristics updated at the period 1951-2012

${ }^{\mathrm{b}}$ Mean 237.5 (for 1951-2010)

${ }^{\mathrm{c}}$ Mean 1,133 (for 1951-2010)
}

\begin{tabular}{|c|c|c|}
\hline Precipitation characteristics & Kasprowy Wierch & Zakopane \\
\hline Maximum daily precipitation $(\mathrm{mm})^{\mathrm{a}}$ & $232(1973)$ & $138.7(1970,1973)$ \\
\hline Mean of maximum daily precipitation $(\mathrm{mm})^{\mathrm{a}}$ & 80.0 & 63.9 \\
\hline Maximum 3-day precipitation $(\mathrm{mm})^{\mathrm{a}}$ & $298.3(1973)$ & $197.1(1970,1973)$ \\
\hline Mean of maximum 3-day precipitation (mm) & 140.2 & 105.6 \\
\hline Maximum 5-day precipitation $(\mathrm{mm})^{\mathrm{a}}$ & $388.7(1980)$ & $235.9(1972)$ \\
\hline Mean of maximum 5-day precipitation (mm) & 168.6 & 126.4 \\
\hline Maximum 7-day precipitation (mm) & $403.1(1980)$ & $273.3(1972)$ \\
\hline Mean of maximum 7-day precipitation (mm) & 189.0 & 140.5 \\
\hline Maximum 1-month precipitation $(\mathrm{mm})^{\mathrm{a}}$ & 651.4 (July 2001) & 439.2 (July 2001) \\
\hline Mean maximum 1-month precipitation (mm) & 307.5 & $233.2^{\mathrm{b}}$ \\
\hline Maximum seasonal precipitation, winter $(\mathrm{mm})^{\mathrm{a}}$ & $643(1962)$ & $303(1952)$ \\
\hline Maximum seasonal precipitation, spring $(\mathrm{mm})^{\mathrm{a}}$ & $721(1978)$ & $520(2010)$ \\
\hline Maximum seasonal precipitation, summer $\left(\mathrm{mm}^{\mathrm{a}}\right)$ & $1,254(2001)$ & $787(1960)$ \\
\hline Maximum seasonal precipitation, autumn $(\mathrm{mm})^{\mathrm{a}}$ & $748(1964)$ & $459(1952)$ \\
\hline Maximum annual precipitation $(\mathrm{mm})^{\mathrm{a}}$ & $2,599(2001)$ & $1,646(2010)$ \\
\hline Mean annual precipitation $(\mathrm{mm})^{\mathrm{a}}$ & 1,759 & $1,122^{\mathrm{c}}$ \\
\hline Minimum annual precipitation $(\mathrm{mm})^{\mathrm{a}}$ & $1,292(1993)$ & $811(1993)$ \\
\hline Maximum 95th percentile of daily precipitation ( $\mathrm{mm})$ & $31.2(2001)$ & $19.7(1960)$ \\
\hline Mean of 95th percentiles of daily precipitation (mm) & 21.4 & 15.1 \\
\hline Maximum 99th percentile of daily precipitation (mm) & $68.7(2001)$ & $43.8(1980)$ \\
\hline Mean of 99th percentiles of daily precipitation (mm) & 43.2 & 32.7 \\
\hline Number of days with precipitation $\geq 10 \mathrm{~mm}$ & $79(1962)$ & $44(1964,2001)$ \\
\hline Mean number of days with precipitation $\geq 10 \mathrm{~mm}$ & 56 & 33 \\
\hline $\begin{array}{l}\text { Proportion of precipitation in the days with precipitation } \\
\geq 10 \mathrm{~mm} \text { in the annual precipitation total (\%) }\end{array}$ & $81(1962,2001)$ & $73(1959)$ \\
\hline $\begin{array}{l}\text { Mean proportion of precipitation in the days with precipitation } \\
\geq 10 \mathrm{~mm} \text { in the annual precipitation total }(\%)\end{array}$ & 68 & 60 \\
\hline Number of days with precipitation $\geq 20 \mathrm{~mm}$ & $40(2001)$ & $19(1960,1974)$ \\
\hline Mean number of days with precipitation $\geq 20 \mathrm{~mm}$ & 22 & 11 \\
\hline $\begin{array}{l}\text { Proportion of precipitation in the days with precipitation } \\
\geq 20 \mathrm{~mm} \text { in the annual precipitation total }(\%)\end{array}$ & $62(2001)$ & 49 (1960) \\
\hline $\begin{array}{l}\text { Mean proportion of precipitation in the days with precipitation } \\
\geq 20 \mathrm{~mm} \text { in the annual precipitation total (\%) }\end{array}$ & 40 & 33 \\
\hline
\end{tabular}


occurred during a northern cyclonic situation (Nc). On 16 July 1934, $172 \mathrm{~mm}$ of precipitation was recorded in Zakopane, whereas $684 \mathrm{~mm}$ of precipitation was recorded during the "flood month" in July 1934 at Hala Gasienicowa. Table 3 provides a comprehensive characterization of precipitation at the stations of Kasprowy Wierch and Zakopane (Pińskwar 2009, 2010), updated where possible, to cover the period 1951-2012. An increase in many annual indices has been observed in the series, but trends typically are not statistically significant (Pińskwar 2009, 2010). Significant upward trends in some extreme precipitation indices have been observed at the seasonal scale and for the period 1951-2007. At Kasprowy Wierch, increases in the frequency of occurrence and in precipitation totals have been found for autumn and for days with 24 -h precipitation $\geq 10,20$ and $30 \mathrm{~mm}$ as well as at the 95th percentile level. At Zakopane station, significant increases in some indices (i.e. number of days with precipitation $\geq 20 \mathrm{~mm}$, precipitation totals from days with 24-h precipitation $\geq 10$ and $20 \mathrm{~mm}$ as well as at the 95th percentile level) have been found in winter (Lupikasza 2010).

The highest precipitation totals, which typically lead to floods in the Tatra Mountains and adjacent foothills and lowlands, usually occur between May and October. In Zakopane, precipitation totals during this time of the year ranged from $532 \mathrm{~mm}$ in 1993 to $1,285 \mathrm{~mm}$ in 2010. The values for the summit station at Kasprowy Wierch are much higher, ranging from $698 \mathrm{~mm}$ (1993) to $1,765 \mathrm{~mm}$ (2001). Some of these heavy summer rainfalls are clearly linked to thunderstorms (Cebulak and Niedźwiedź 1998). These events are of highest intensity and local dimension and have reached up to $90 \mathrm{~mm} \mathrm{~h}^{-1}$ in Zakopane (16 June 1977), with subsequent serious damage (Niedźwiedź and Szpetman 1978).

\section{Changes in intense precipitation}

Positive but insignificant trends exist in precipitation totals of the warm half-year (May-October), with magnitudes exceed-

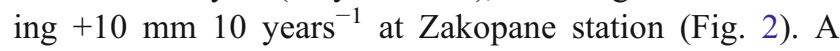
relatively dry period ending in 1957 was followed by two periods characterized by higher precipitation totals (19581981 and 1996-2010). Highest rainfall totals are typically recorded during summer (June-August). Seasonal totals in summer varied from $265 \mathrm{~mm}$ (1990) to $769 \mathrm{~mm}$ (2001) in Zakopane and from $300 \mathrm{~mm}$ (1990) to $1,254 \mathrm{~mm}$ (2001) at Kasprowy Wierch. No significant long-term trends were observed in the time series of summer precipitation (Fig. 2), and fluctuations in precipitation have been observed to be similar to those of warm half-year totals.

The average maximum daily precipitation total at Zakopane station, calculated from annual maximum daily totals for the period 1951-2012, was $63.9 \mathrm{~mm}$ with minima and maxima recorded at $29.8 \mathrm{~mm}$ (1993) and $138.9 \mathrm{~mm}$ (1970, 1973), respectively. Six other years occurred where the maximum daily precipitation total passed the threshold of $100 \mathrm{~mm}: 101.3 \mathrm{~mm}$ in $1960,108.2 \mathrm{~mm}$ in $1962,109.2 \mathrm{~mm}$ in $1983,109.4 \mathrm{~mm}$ in $1985,104.0 \mathrm{~mm}$ in 1997 and $113.5 \mathrm{~mm}$ in 2008. In addition to the extremely low value recorded in 1993, 7 years are observed where the maximum 24-h precipitation total did not exceed $40 \mathrm{~mm}$, namely, in 1954
Fig. 2 Long-term variability of warm half-year (May-October) and summer (June-August) precipitation (1951-2012). The solid line indicates the linear trend, and the dashed line presents the fifth step of polynomial trend

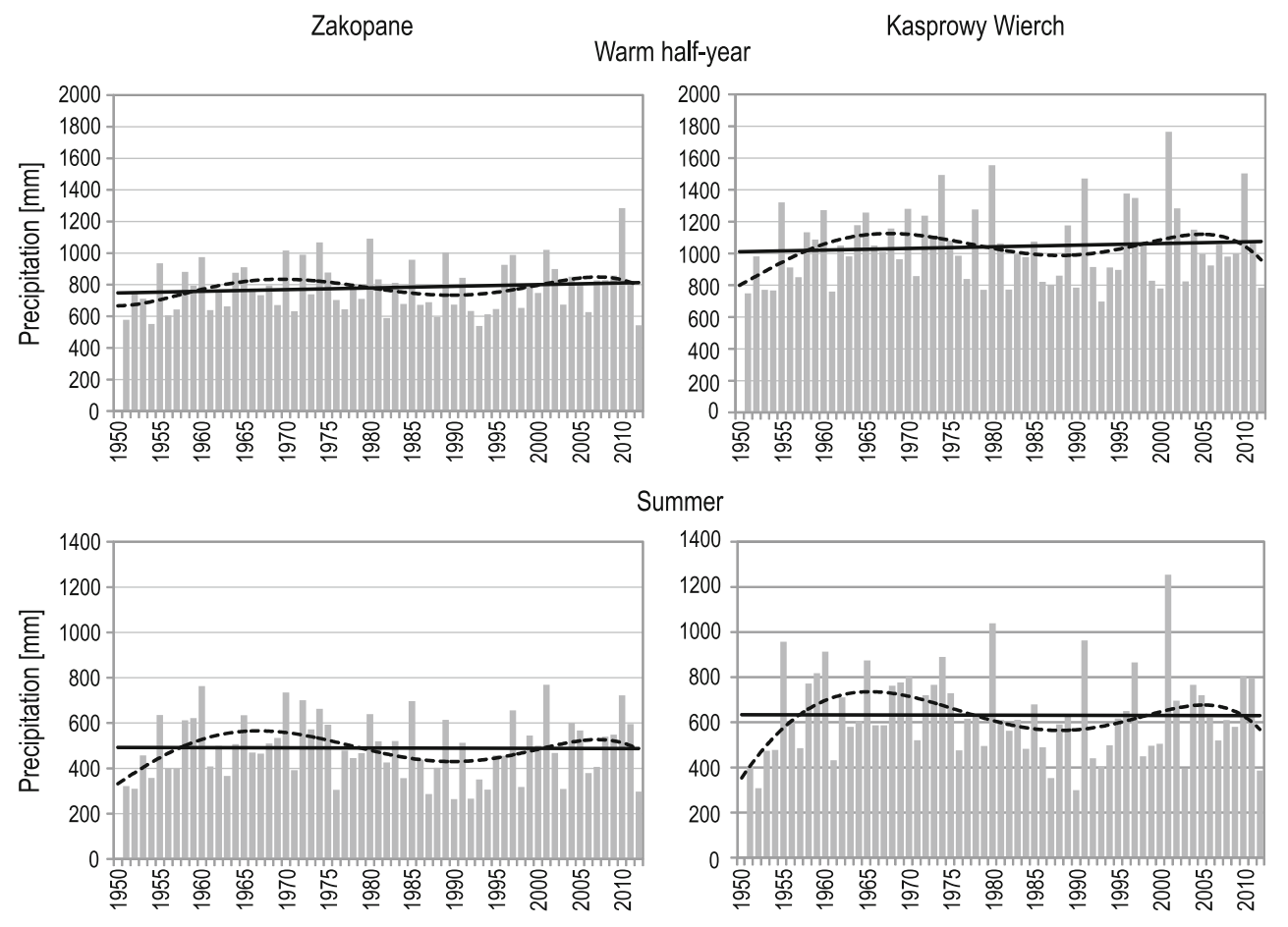


(34.8 mm), $1979(38.0 \mathrm{~mm}), 1982(34.2 \mathrm{~mm}), 1990$ $(33.4 \mathrm{~mm})$ and $1998(38.6 \mathrm{~mm})$. Daily precipitation totals below the 1-day $40-\mathrm{mm}$ threshold occurred in the last years of the period under investigation with 36.0 and $31.5 \mathrm{~mm}$ for 2011 and 2012, respectively. A statistically insignificant downward trend in maximum daily precipitation totals can be observed and has a magnitude of $-2.1 \mathrm{~mm} 10$ years $^{-1}$ in Zakopane (Fig. 3). At shorter-time scales, however, a significant downward tendency can be recognized for the period

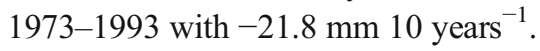

The average maximum daily precipitation total at Kasprowy Wierch, located ca. 1,100 m above Zakopane, amounts to $80 \mathrm{~mm}$. The largest maximum 24-h precipitation total was recorded on 30 June 1973 with $232.0 \mathrm{~mm}$ and exceeded the average value by more than 4 standard deviations. The lowest maximum of daily precipitation totals was also noted in 1990 and 1992, at Zakopane, and amounted to $36.4 \mathrm{~mm}$. Various statistical trends can be observed in the long-term course of the index (Fig. 3). Weak, short-term tendencies occurred in the same periods as in Zakopane station, namely, in 1951-1973 (increase), 1973-1993 (decrease) and 1993-2010 (increase).

The most damaging floods of the Tatra Mountains typically result from precipitation lasting incessantly over 3 to 5 days. For example, on 16-18 July 1934, the highest 3-day total reached $422 \mathrm{~mm}$ at Hala Gassienicowa (Niedźwiedź 2003a). In Zakopane, by contrast, the highest 3-day precipitation total did not exceed $200 \mathrm{~mm}$ between 1951 and 2012. At Kasprowy Wierch, 3-day precipitation totals exceeded $200 \mathrm{~mm}$ eight times between 1962 and 2001 (Fig. 3).

Daily precipitation totals trespassing 30 and $50 \mathrm{~mm}$ are considered extreme events in the context of the Polish Tatra Mountains. The average number of days with precipitation $\geq 30 \mathrm{~mm}$ is 5 in Zakopane and 9 at Kasprowy Wierch. In Zakopane, the largest number of threshold exceedances was recorded in 1989 with 11 days, whereas at Kasprowy Wierch,
Fig. 3 Long-term variability of maximum daily, maximum 3-day and maximum 5-day precipitation totals (1951-2012). For details, see Fig. 2
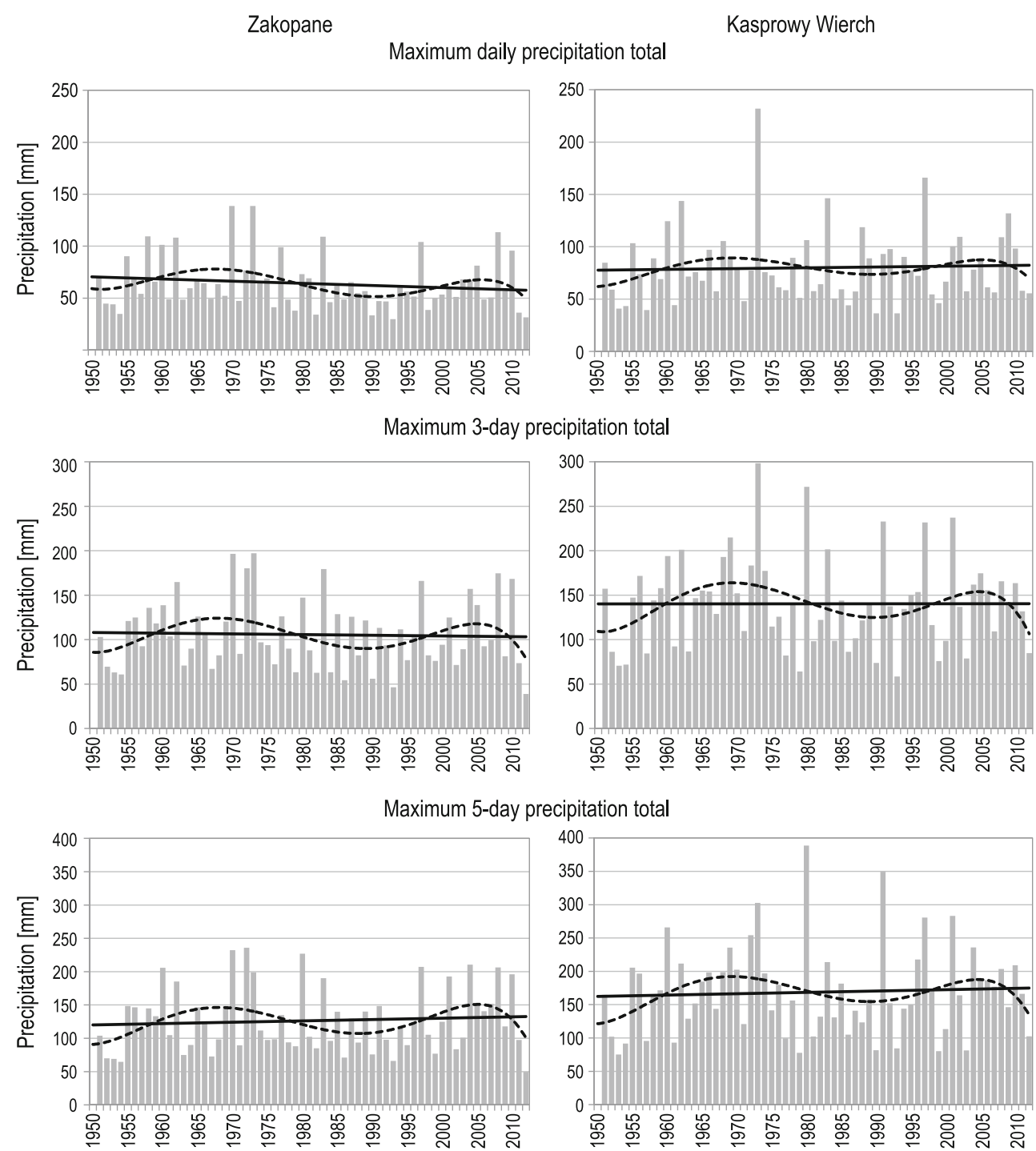
the highest number was recorded in 2001 with 20 days. The $30-\mathrm{mm}$ threshold was not passed in Zakopane in 1993. At Kasprowy Wierch station, the minimum number of threshold exceedances ( 2 days) was noted in 1999. The trend calculated for the entire period shows a decrease in the number of annual threshold exceedances at Kasprowy Wierch; however, the trend is not statistically significant. Stronger decreasing tendency is noticeable after 1994. No trend in the number of days under discussion is found in Zakopane (Fig. 4).

Daily precipitation totals very rarely cross the threshold of $50 \mathrm{~mm}$. On average, such high 24-h precipitation is recorded once a year in Zakopane and three times a year in Kasprowy Wierch. In Zakopane, years with at least 1 day of precipitation $\geq 50 \mathrm{~mm}$ were recorded in 21 out of 62 cases. Even at Kasprowy Wierch, which is the wettest station in Poland, the threshold was not passed in 9 years (Fig. 4). In Zakopane, an exceptionally high frequency of such heavy precipitation events $\left(50 \mathrm{~mm} 24 \mathrm{~h}^{-1}\right)$ was recorded in 2007 and 2010 with 5 and 7 days, respectively. At Kasprowy Wierch, the maximum numbers of days with precipitation $\geq 50 \mathrm{~mm}$ occurred in 2001 and 1980 with 12 and 11 days, respectively. Both stations exhibit growing, yet insignificant tendencies in the annual number of days with daily precipitation totals $\geq 50 \mathrm{~mm}$ (Fig. 4).

\section{Circulation patterns and high precipitation}

Past dramatic summer floods in southern Poland have been caused typically by prolonged orographic precipitation, lasting for a few days. The occurrence of extreme precipitation thereby strongly depended on air flow direction. At the meteorological stations of Zakopane and Kasprowy Wierch, extreme precipitation occurred most frequently during situations with air flows from the north and north-east, regardless of the kind of the baric centre (Fig. 5). Dependency of intense precipitation occurrence on atmospheric circulation was studied with the circulation type scheme developed by Niedźwiedź (2013), which attributes a $c$ to all cyclonic and an $a$ to anticyclonic situations. Capital letters designate the air flow direction (geostrophic wind: N, NE, E, SE, S, SW, W, $\mathrm{NW}$ ). In addition, the catalogue allows detection of the cyclonic trough with varying air flow direction and atmospheric front $(B c)$ as well as low pressure centres $(C c)$. Anticyclonic situations lacking air flow direction are designated with $\mathrm{Ca}$ in the case of high centres and with $K a$ in the case of anticyclonic wedges (Niedźwiedź 2013).

The relationship between the occurrence of very high daily precipitation ( $\geq 30$ and $\geq 50 \mathrm{~mm}$ ) and circulation types is presented in Fig. 5. Very high precipitation is mostly caused by cyclonic circulation types, and 3 out of the 21 analysed synoptic situations $(\mathrm{Nc}, \mathrm{NEc}$ and $\mathrm{Bc}$ ) are apparently able to cause the most extreme rainfall conditions. These situations are connected to stationary cyclones moving from the Adriatic Sea and crossing the Carpathians east of the Tatra Mountains, following the cyclone trajectory known as track $\mathrm{Vb}$ after van Bebber (1891). When the cyclone is blocked by the anticyclone formed over Eastern Europe, humid air masses are lifted orographically over the northern slopes of the mountains
Fig. 4 Long-term variability of the number of days with precipitation $\geq 30$ and $\geq 50 \mathrm{~mm}$ (1951-2012). For details, see Fig. 2
Zakopane

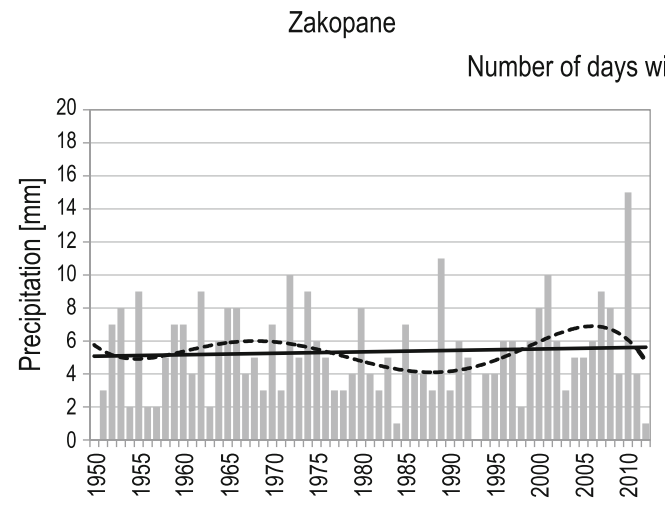

Kasprowy Wierch

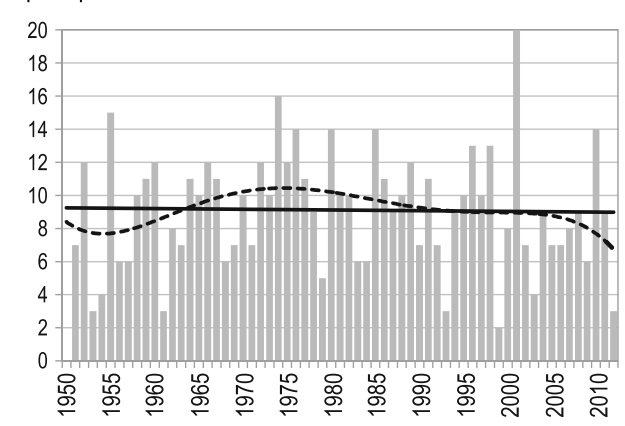

Number of days with precipitation $\geq 50 \mathrm{~mm}$
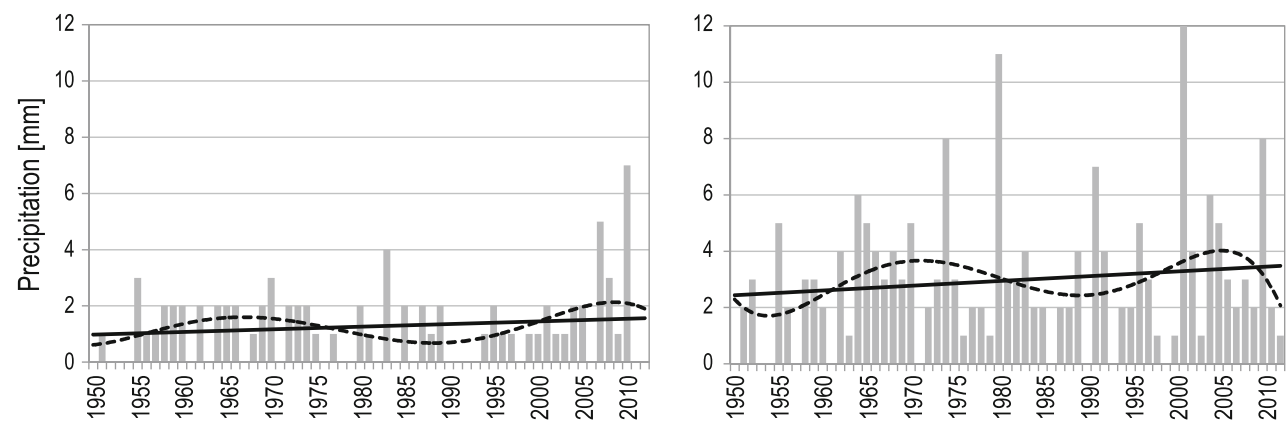
Fig. 5 Number of days with precipitation $\geq 30$ and $\geq 50 \mathrm{~mm}$ and related circulation types (1951-2012). $X$ designates unclassified situation. For details and abbreviations, see text
Zakopane

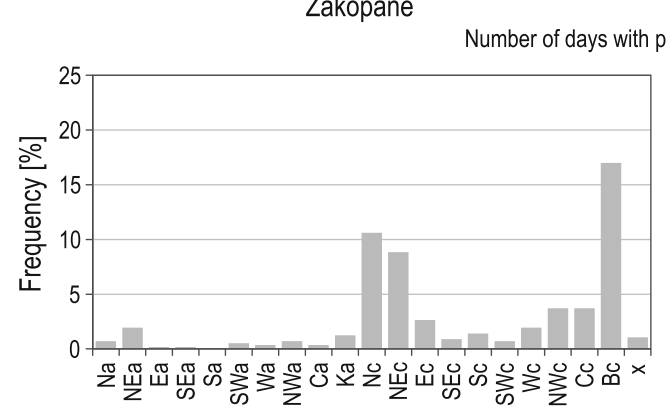

Kasprowy Wierch

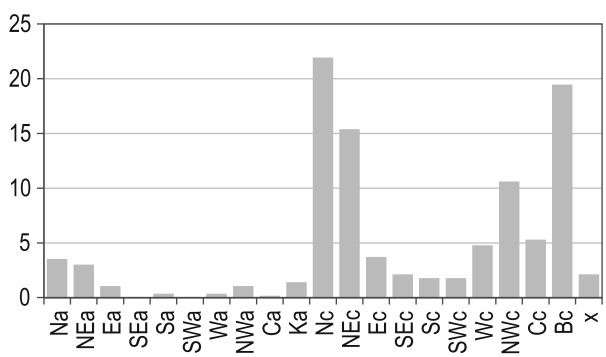

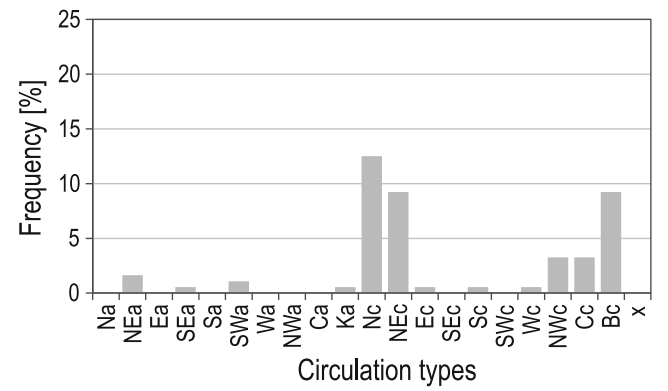

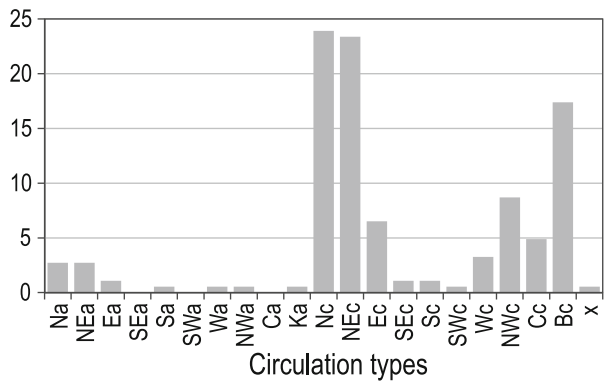

(Carpathians and the Sudetes) and thereby produce prolonged, intense rainfalls (Niedźwiedź 2003a, b). Orography is a crucial precipitation-causing factor in all high mountain areas (Sénési et al. 1996; Buzzi et al. 1998; Massacand et al. 1998; Buzzi and Foschini 2000; Ferretti et al. 2000; Schneidereit and Schär 2000; Houze 2001; Rotunno and Ferretti 2001; Pradier et al. 2004; Seibert et al. 2007). Typical cyclonic circulation types with air advection from the northern sector, cyclonic centre or cyclonic trough have been declared responsible for the most severe precipitation-induced flood events in the region (Morawska-Horawska 1971; Niedźwiedź 2003a, b; Mudelsee et al. 2004; Ustrnul and Czekierda 2001, 2009) as well as in the wider areas of Central Europe (James et al. 2004).

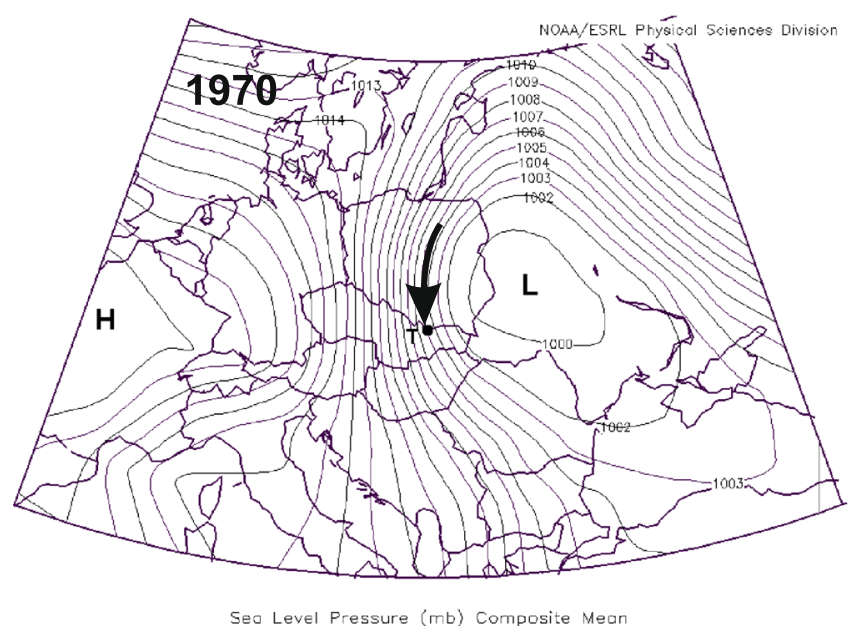

Fig. 6 Composite maps of sea level pressure and geopotential heights of $300,500,700$ and $850 \mathrm{hPa}$ (in millibars) for 9 days with precipitation $\geq 100 \mathrm{~mm}$ recorded at the Zakopane station during the period 1951-2012.
Figure 6 illustrates the spatial distribution of air pressure at sea level and selected geopotential heights $(300,500,700$ and $850 \mathrm{hPa}$ ) based on the NCEP/NCAR reanalysis data set (Kalnay et al. 1996) for 9 days with precipitation $\geq 100 \mathrm{~mm}$ in Zakopane and serious flooding in the Polish Tatras. The combinations of orography and low-pressure systems with centres located over Hungary and Ukraine force the NE advection of moist air over the Tatra Mountains and therefore usually result in heavy precipitation. The distribution of geopotential heights during these situations indicates that the low-pressure system is high with its axis inclined to southwest. Figure 7 shows the distribution of air pressure at sea level during the most severe floods in Poland in July 1970 and

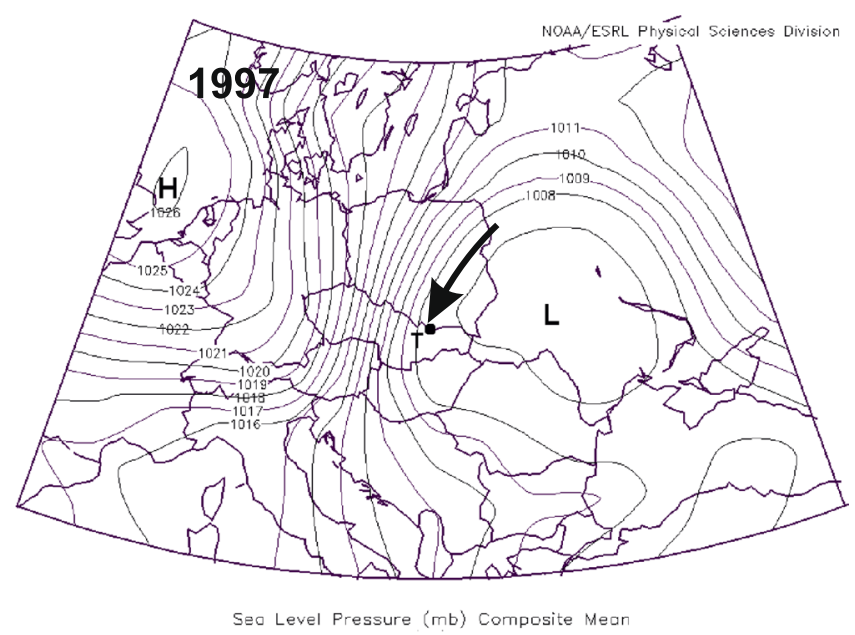

$T$ the Tatra Mountains. Maps were done using the software and databases of the NOAA/ESRL Physical Science Division, Boulder, CO, USA (http://www.esrl.noaa.gov/psd/) 
Fig. 7 Sea level pressure distribution on days with the most severe floods in Poland on 18 July 1970 (Nc circulation type) and 8 July 1997 (NEc circulation type)
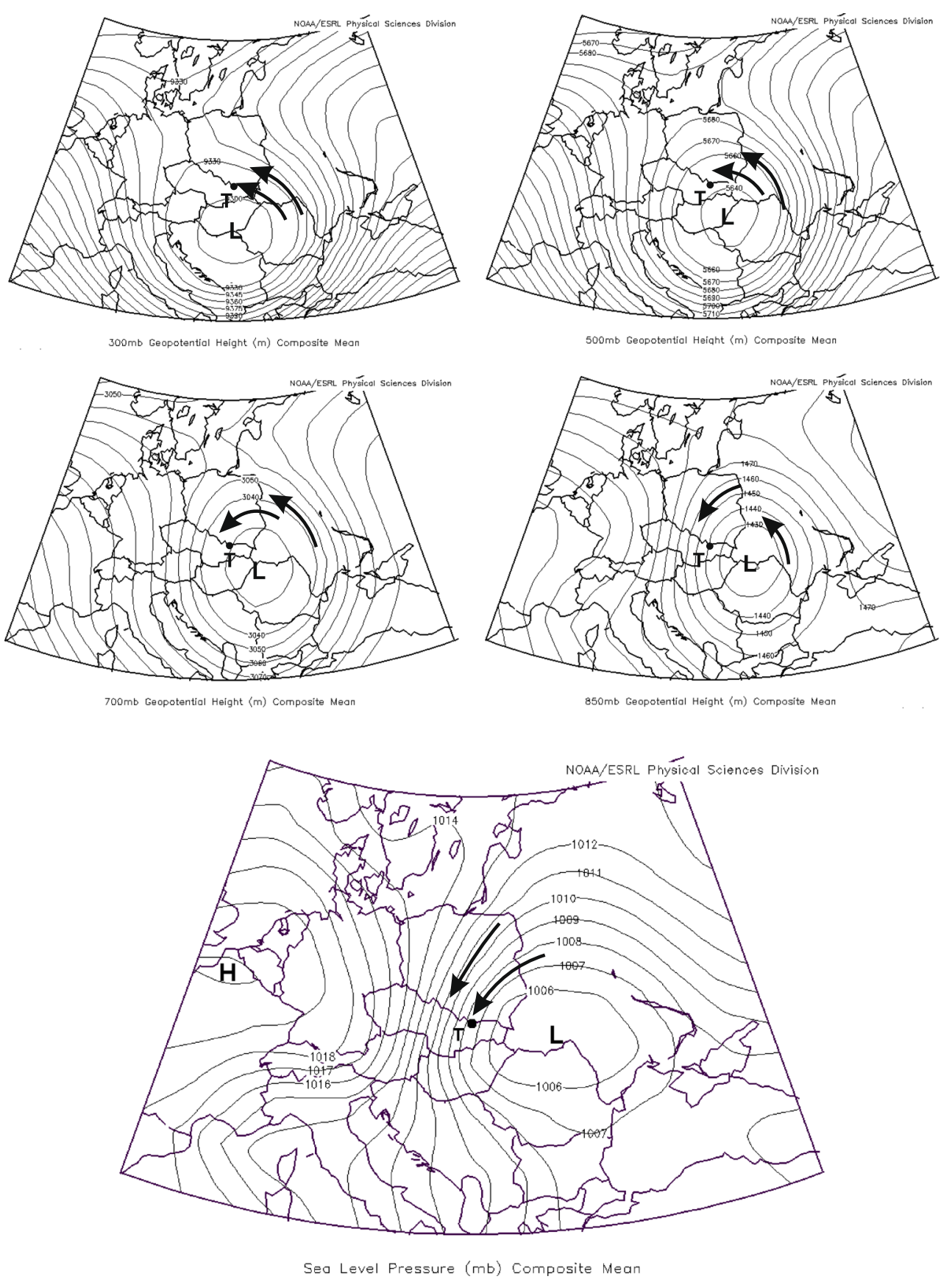

1997. These events were triggered by the classic synoptic situations (Nc and NEc circulation types).

The long-term changes in the frequency of circulation types responsible for the occurrence of intense precipitation $(\mathrm{Nc}+\mathrm{NEc}+\mathrm{Bc})$, shown in Fig. 6, give a hint as to possible future change in the frequency of extreme precipitation. The statistically significant increasing trend in the number of days with $\mathrm{Nc}+\mathrm{NEc}+\mathrm{Bc}$ circulation types (3 days per 10 years) could possibly lead to an increase in the number of extreme precipitation events. Along this line of thoughts, we recognize that the largest number of days with these circulation types occurred in 2010 (84 days), when the largest annual and warm half-year precipitation totals were recorded. The long-term trend in the number of days with circulation types that are most favourable for the occurrence of exceptionally high daily totals, exceeding $100 \mathrm{~mm}$ a day, is linked to $\mathrm{Nc}+\mathrm{NEc}$ situations. The occurrence of this pattern is decreasing overall; however, the growing tendency beginning in the mid-1990s is noticeable (Fig. 8).

The vigorousness of dynamic processes leading to the occurrence of precipitation depends on the nature of the meteorological front and its origin (e.g. cold front, warm front, etc.). Atmospheric conditions favouring the occurrence of precipitation may also develop within the air mass of uniform 
Fig. 8 Long-term variability of the number of days with the circulation types $(\mathrm{Nc}+\mathrm{NEc}+\mathrm{Bc})$ triggering the extreme precipitation (1951-2012). Explanations as in Fig. 2

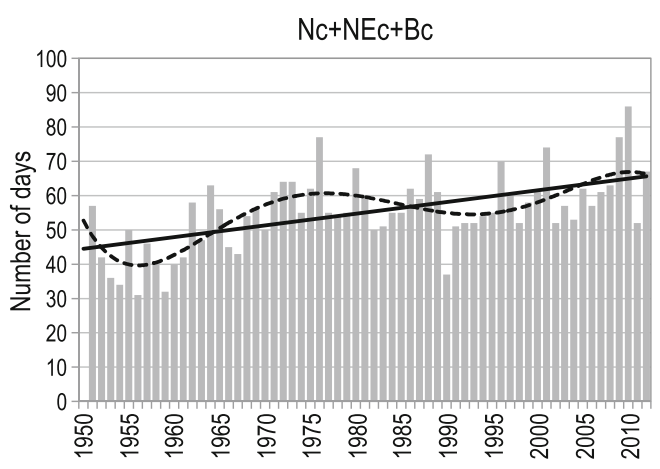

temperature and humidity (non-frontal precipitation). The largest number of precipitation events $\geq 30$ and $\geq 50 \mathrm{~mm}$ occurring at Zakopane and Kasprowy Wierch is non-frontal (ca. $40 \%$ of all cases); this fact points quite clearly to the crucial role of orography in precipitation-causing processes. Cold fronts are another synoptic situation that has been responsible for extreme precipitation events in the past. More than $25 \%$ of precipitation events $\geq 30 \mathrm{~mm}$ and ca. $20 \%$ of events $\geq 50 \mathrm{~mm}$ have been caused by cold fronts. The smallest number of days with extreme precipitation is, in contrast, related to warm and stationary fronts (Fig. 9).

\section{Conclusions}

The meteorological stations in the Polish Tatra Mountains record the largest precipitation totals of the country, and intense and long-lasting precipitation in this region has also
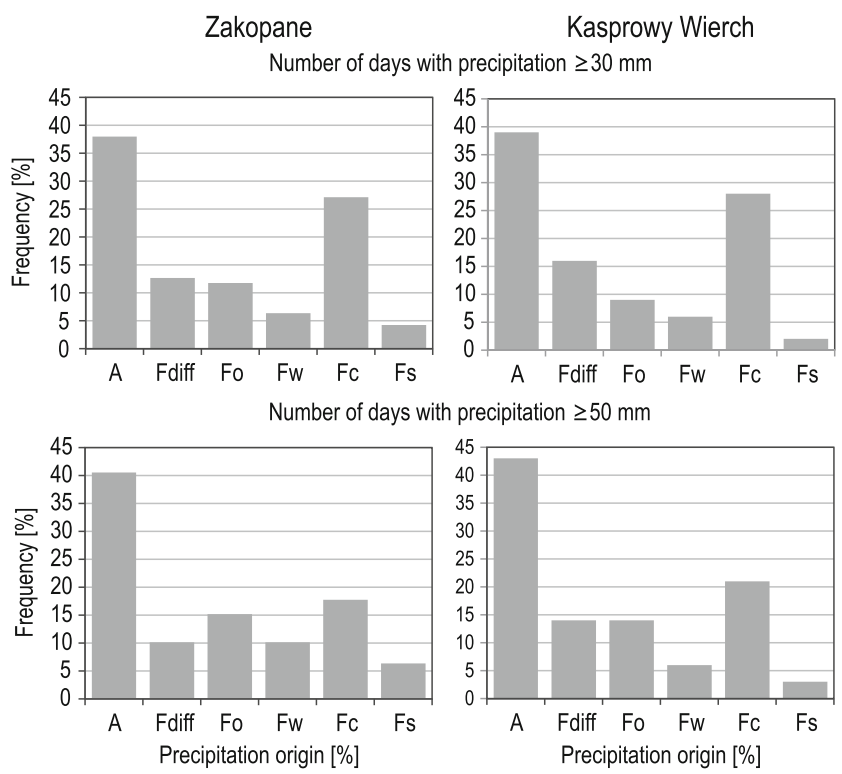

Fig. 9 Frequency of intense precipitation and related synoptic situations. $A$ non-frontal precipitation, Fdiff precipitation linked to the passage of various fronts, $F o$ precipitation linked to occlusions, $F w$ warm front precipitation, $F_{C}$ cold front ping a web site. Provide a few examples/ references been responsible for several large floods that were initiated in the Tatra Mountains and its foothills and propagated downstream to the River Vistula (Morawska-Horawska 1971; Niedźwiedź 1999; Niedźwiedź et al. 1999; Starkel 2001).

The FLORIST project will contribute to an improved understanding and a reduction of uncertainty in the interpretation of changes in the frequency and magnitude of intense precipitation, torrential processes and river floods in mountainous watersheds (Kundzewicz et al. 2013) and will possibly help to improve current evidence which often remains conflicting. Indications exist for an increase in the frequency and intensity of heavy precipitation events (Kundzewicz et al. 2006) in some parts of Poland, but the signal is not persistent. The fact that results remain contradictory and that they differ significantly between different regions within Poland clearly highlights the necessity to continue efforts to solve this problem of vast practical relevance and to launch projects at the local and regional scales.

Climate models predict increased duration, severity and frequency of intense precipitation over some areas of Poland which, in turn, might translate into increased climate-related flood risks (Kundzewicz and Schellnhuber 2004). However, current knowledge of these processes in mountainous and piedmont areas of Poland is based on existing observational records. As a matter of fact, results of these studies will typically be study- and site-specific and depend on the model(s) used. A generalization of case-study conclusions does not therefore seem possible.

An increase in several annual indices of extreme precipitation in the foothills of the Tatra Mountains has been observed in this study, but trends typically are not statistically significant. Clearly, changes in annual and seasonal indices of intense precipitation in Zakopane and Kasprowy Wierch, as described in this paper, are dominated by natural variability which might eventually blur some of the possible trends. Trend directions may also vary between the stations investigated; in three out of seven indices analysed in this contribution (i.e. maximum daily precipitation totals, 3-day precipitation total, number of days with precipitation $\geq 30 \mathrm{~mm}$ ), opposing trends exist between Zakopane and Kasprowy Wierch. In contrast, both stations exhibit upward trends in maximum 
daily, maximum 5-day and summer half-year precipitation totals as well as in the frequency of days with precipitation $\geq 50 \mathrm{~mm}$, but none of the trends were statistically significant.

Three cyclonic circulation types have been identified in this paper to be responsible for the triggering of the most extreme rainfall conditions in the Tatra Mountains, namely, Nc, NEc and $\mathrm{Bc}$. These situations are connected to stationary cyclones originating in the Adriatic Sea and propagating with track $\mathrm{Vb}$ after van Bebber (1891). However, despite circulation, orography has proven to play a crucial role in the formation of intense precipitation in the area under investigation. In this sense, most occurrences of intense precipitation events evolve in air masses of uniform temperature and humidity (non-frontal precipitation). In conclusion, the long-term increase in the frequency of circulation types responsible for the largest frequency of extreme precipitation has been documented in this paper and may provide hints as to future changes in extreme precipitation in the Polish Tatra Mountains.

Acknowledgments This contribution has been supported by the FLORIST (Flood risk on the northern foothills of the Tatra Mountains) project, PSPB no. 153/2010, through a grant from Switzerland through the Swiss Contribution to the enlargement of the European Union. The project makes use of hydrometeorological data provided by the Institute of Meteorology and Water Management-State Research Institute (IMGW-PIB) and data published (1954-1981) in the annals "Opady Atmosferyczne". Data for the period 2000-2012 have been obtained from the SYNOP messages database OGIMET. Images of synoptic maps were retrieved from the NOAA/ESRL Physical Sciences Division, Boulder Colorado (http://www.esrl.noaa.gov/psd/) and from the NCEP/NCAR reanalysis data set.

Open AccessThis article is distributed under the terms of the Creative Commons Attribution License which permits any use, distribution, and reproduction in any medium, provided the original author(s) and the source are credited.

\section{References}

Buzzi A, Foschini L (2000) Mesoscale meteorological features associated with heavy precipitation in the southern Alpine region. Meteorog Atmos Phys 72:131-146

Buzzi A, Tartaglione N, Malguzzi P (1998) Numerical simulations of the 1994 Piedmont flood: role of orography and moist processes. Mon Weather Rev 126:2369-2383

Cebulak E, Niedźwiedź T (1998) Ekstremalne zjawiska opadowe w Dorzeczu Górnej Wisły w latach 1995 i 1996 (Extreme precipitation events in the upper Vistula river basin in the years 1995 and 1996). In: Starkel L (ed) Geomorfologiczny i sedymentologiczny zapis lokalnych ulew (Geomorphological and sedimentological record of the local downpours). Dokumentacja Geograficzna 11:11-30

Falarz M (2002) Long-term variability in reconstructed and observed snow cover over the last 100 winter seasons in Cracow and Zakopane (southern Poland). Clim Res 19:247-256

Falarz M (2013) Seasonal stability of snow cover in Poland in relation to the atmospheric circulation. Theor Appl Climatol 111(1):21-28

Ferretti R, Low-Nam S, Rotunno R (2000) Numerical simulations of the Piedmont flood of 4-6 November 1994. Tellus 52A:162-180
Heino R, Brázdil R, Førland E, Tuomenvirta H, Alexandersson H, Beniston M, Pfister C, Rebetez M, Rosenhagen G, Rösner S, Wibig J (1999) Progress in the study of climatic extremes in Northern and Central Europe. Clim Chang 42:151-181

Hess M (1965) Piętra klimatyczne w polskich Karpatach Zachodnich (Vertical climatic zones in the Polish Western Carpathians). Zesz Nauk UJ Pr Geograficzne 11:1-267 (in Polish)

Hess M (1974) Piętra klimatyczne w Tatrach (Vertical climatic zones in the Tatra Mountains). Czasopismo Geograficzne 45(1):75-95 (in Polish, English summary)

Houze RA Jr (2001) Orographic control of precipitation: what are we learning from MAP? MAP Newsl 14:3-5

James P, Stohl A, Spichtinger N, Eckhardt S, Forster C (2004) Climatological aspects of the extreme European rainfall of August 2002 and a trajectory method for estimating the associated evaporative source regions. Nat Hazards Earth Syst Sci 4:733-746

Kalnay E et al (1996) The NCEP/NCAR reanalysis 40-year project. Bull Am Meteorol Soc 77:437-471

Konček M (ed) (1974) Klima Tatier (Climate of the Tatras). Veda, Bratislava. $856 \mathrm{p}$ (in Slovak)

Kundzewicz ZW, Schellnhuber H-J (2004) Floods in the IPCC TAR perspective. Nat Hazards 31:111-128

Kundzewicz ZW, Radziejewski M, Pińskwar I (2006) Precipitation extremes in the changing climate of Europe. Clim Res 31:51-58

Kundzewicz ZW, Stoffel M, Kaczka RJ, Wyżga B, Niedźwiedź T, Pińskwar I, Ruiz-Villanueva V, Łupikasza E, Czajka B, Ballesteros-Canovas JA, Małarzewski Ł, Choryński A, Janecka K, Mikuś P (2013) Floods at the northern foothills of the Tatra Mountains - a Polish-Swiss research project. Acta Geophys (in print)

Lorenc H (ed) (2005) Atlas klimatu Polski (Atlas of the Poland climate). IMGW, Warszawa (in Polish)

Łupikasza E (2010) Spatial and temporal variability of extreme precipitation in Poland in the period 1951-2006. Int J Climatol 30(7):9911007

Massacand AC, Wernli H, Davies HC (1998) Heavy precipitation on the Alpine south side: an upper-level precursor. Geophys Res Lett 25: $1435-1438$

Morawska-Horawska M (1971) Meteorologiczne przyczyny powodzi w Polsce Południowej w lipcu 1970 r. (Meteorological causes of the flood in July 1970 in Southern Poland). Przeglad Geofizyczny 16(24)4:299-315

Mudelsee M, Börngen M, Tetzlaf G, Grünewald U (2004) Extreme floods in Central Europe over the past 500 years: role of cyclone pathway "Zugstrasse Vb". J Geophys Res 109(D23101):1-21

Niedźwiedź T (1992) Climate of the Tatra Mountains. Mt Res Dev 12(2): 131-146

Niedźwiedź T (1999) Rainfall characteristics in southern Poland during the severe flooding event of July 1997. Stud Geomorphol Carpatho Balc 33:5-25

Niedźwiedź T (2003a) Extreme precipitation events on the northern side of the Tatra Mountains. Geogr Pol 76(2):13-21

Niedźwiedź T (2003b) The extreme precipitation in Central Europe and its synoptic background. Pap Glob Chang IGBP 10:15-29

Niedźwiedź T (2013) Calendar of circulation types for territory of southern Poland (09.1873-12.2012). Computer file available on line at the Department of Climatology, University of Silesia http://klimat. wnoz.us.edu.pl

Niedźwiedź T, Szpetman Z (1978) Charakterystyka katastrofalnej ulewy w Zakopane, w dniu 16.VI.1977 r. (The characteristics of the disastrous rainfall on 16 June 1977 in Zakopane). Wiadomości IMGW 4(14)4:103-108

Niedźwiedź T, Cebulak E, Czekierda D, Limanówka D (1999) Wysokość, natężenie i przestrzenny rozkład opadów atmosferycznych (The precipitation events, their magnitude, intensity and spatial distribution). In: Monografia Powodzi lipiec $1997-$ 
Dorzecze Wisty (Flood monograph of July 1997 - Vistula Basin), IMGW, Warszawa, pp 23-42

Pińskwar I (2009) Projekcje zmian w ekstremach opadowych w Polsce (Projections of changes in precipitation extremes in Poland). Doctoral dissertation, Department of Melioration and Environmental Engineering, University of Life Sciences in Poznań, Poland

Pińskwar I (2010) Projekcje zmian w ekstremach opadowych w Polsce (Projections of changes in precipitation extremes in Poland). Monografie Komitetu Gospodarki Wodnej PAN. Warszawa 32:1-153

Pradier S, Chong M, Roux F (2004) Characteristics of some frontal stratiform precipitation events south of the Alpine chain during MAP. Meteorog Atmos Phys 87:197-218

Rotunno R, Ferretti R (2001) Mechanisms of intense Alpine rainfall. J Atmos Sci 58:1732-1749

Schneidereit M, Schär C (2000) Idealised numerical experiments of Alpine flow regimes and southside precipitation events. Meteorog Atmos Phys 72:233-250
Seibert P, Frank A, Formayer H (2007) Synoptic and regional patterns of heavy precipitation in Austria. Theor Appl Climatol 87:139-15

Sénési SP, Bougeault P, Cheze JL, Cosentino P, Thepenier R (1996) The Vaison-La-Romaine flash flood: mesoscale analysis and predictability issues. Weather Forecast 11:417-442

Starkel L (2001) Extreme rainfall and river floods in Europe during the last millennium. Geogr Pol 74(2):69-79

Ustrnul Z, Czekierda D (2001) Circulation background of the atmospheric precipitation in Central Europe (based on the Polish example). Meteorol Z 10(2):103-111

Ustrnul Z, Czekierda D (2009) Atlas of extreme meteorological phenomena and synoptic situations in Poland. Instytut Meteorologii i Gospodarki Wodnej, Warszawa, pp 1-182

Valor GB (2013) OGIMET — professional information about meteorological conditions in the world. SYNOP messages available online. http://www.ogimet.com. Accessed 15 May 2013

van Bebber WJ (1891) Die Zugstrassen der barometrischen Minima. Meteorol Z 8:361-366 